\title{
An Assessment of Gully Erosion in Gombe Town, Gombe State,
} Nigeria

\author{
Lazarus Abore Mbaya ${ }^{1}$, H. K. Ayuba ${ }^{2} \&$ John Abdullahi ${ }^{2}$ \\ ${ }^{1}$ Department of Geography, Gombe State University, Gombe, Nigeria \\ ${ }^{2}$ Departments of Geography, University of Maiduguri, Borno State, Nigeria \\ Correspondence: Lazarus Abore Mbaya, Department of Geography, Gombe State University, PMB 127, Gombe, \\ Nigeria. Tel: 234-802-447-3050. E-mail: lazarusambaya@yahoo.com
}

Received: January 29, 2012 Accepted: February 14, 2012 Online Published: August 10, 2012

doi:10.5539/jgg.v4n3p110 URL: http://dx.doi.org/10.5539/jgg.v4n3p110

\begin{abstract}
The development of gullies is one of the severe environmental problems in Gombe town. It has threatens urban infrastructure, properties, lives and the physical growth of the town. Knowing the rates of gully development in the last decade helped explain the reasons for current land degradation. This research work therefore assessed gully erosion in Gombe town. Data used in this study were derived from field measurements, satellite imageries, and laboratory analysis and questionnaire survey. Results from the interpretation of Spot 5(1999) and Quick Birds (2009) imageries and field measurements showed that gully variables (length, depth and widths) have significantly increased in the last 10 years. Laboratory analysis of soil particle size revealed that sand proportion was $52 \%$, silt $9.5 \%$ and clay $38.5 \%$. The values of Atterberg limits (liquid limits; plasticity limit and the plasticity index (PI), shear strength (cohesion and angle of internal friction) and bulk density values were low, soil chemical properties also showed that the soils are moderately acidic, contained low organic matter, and low exchangeable cations, with serious implication on biological methods of erosion control.
\end{abstract}

Keywords: gully erosion, landuse, soil properties, rainfall, topography and Gombe town

\section{Introduction}

The formation of gullies has become one of the greatest environmental disasters facing Gombe town. The town is fast becoming hazardous for human habitation. Hundreds of people are directly affected every year and have to be re-located. Large areas of lands are becoming unsuitable for human settlements (Mbaya, 2012). The situation is getting worse annually, since Gombe town assumed the status of state capital in 1996. The infrastructural development coupled with demographic increase, have heightened the problems of gully erosion in the state capital. People have observed, some small rills, which were crossed with one-footstep, that have now developed into big gullies and those that have their houses at reasonable distances from such rills some years back are now helplessly observing their houses collapsing or with exposed foundations. Residents of Gombe town have expressed concern over accelerated erosion rates. These concerns address not only the loss of personal property, but also that gully erosion is causing functional and structural damage to infrastructures such as culvert outlets and roads within the stream channels as well as other public and private structures along the channel. Federal and State Government have attempted to arrest the problem through numerous contracts awarded for gully erosion projects at some key sites in Gombe town. However, the economic practicalities and engineering control measures has not met people expectation, owing to lack of adequate information on the topography, soil and geology, rainfall characteristics, catchment area and land use pattern of a town experiencing rapid growth (Mbaya, 2012) . Therefore, solving the gully erosion problem in Gombe town requires concerted research efforts. The main aim of this research was to assess the rate and factors of gully system in the study area.

\section{The Study Area}

Gombe town is located between latitudes $10^{\circ}$ to $10^{\circ} 20^{\prime} \mathrm{N}$ and longitudes $11^{\circ} 01^{\prime} \mathrm{E}$ and $11^{\circ} 19^{\prime} \mathrm{E}$ (Figure 1). It shares common boundary with Akko LGA in the South and West; Yamaltu-Deba to the East and Kwami to the North. It is the capital of Gombe State and occupies an area of about $45 \mathrm{~km}^{2}$ (Ministry of Land and Survey, Gombe, 2008). Gombe town is well linked by road to other regional centres like Biu / Maiduguri, Potiskum / Damaturu, Bauchi /Jos and Yola /Jalingo. A single gauge railway line on the Bauchi - Maiduguri route also links 
the town, in addition to an international airport. The climate of Gombe is characterized by a dry season of six months, alternating with a six months rainy season. As in other parts of the Nigerian Savanna this precipitation distribution is mainly triggered by a seasonal shift of the Inter -Tropical Convergence Zone (ITCZ). For the years 1977 to 1995 , the mean annual precipitation is $835 \mathrm{~mm}$ and the mean annual temperature is about $26^{\circ} \mathrm{C}$ whereas relative humidity has same pattern being $94 \%$ in August and dropping to less than $10 \%$ during the harmattan period (Balzerek et al., 2003).

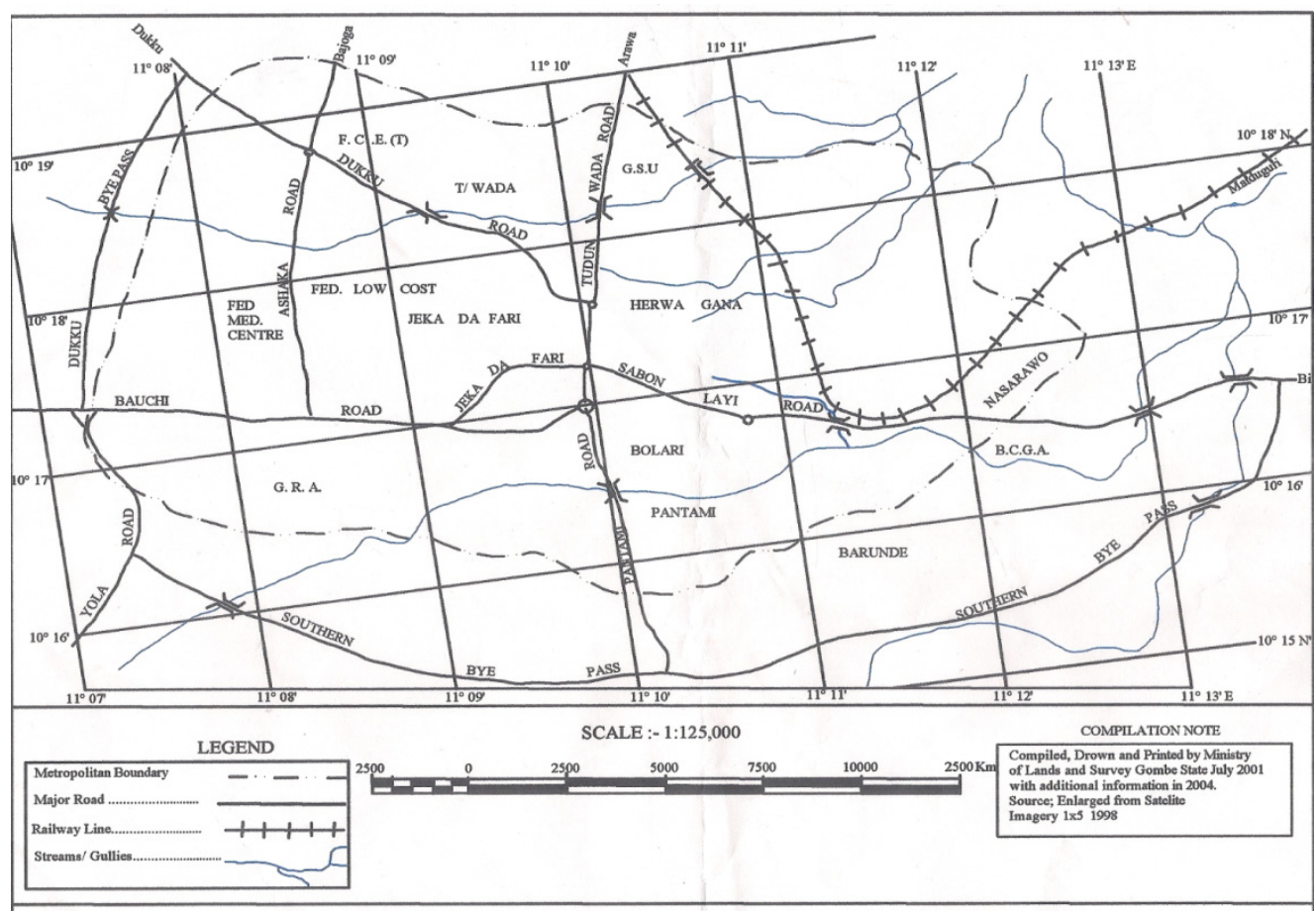

Figure1. Gully erosion of the study area (Source: Ministry of Environment and Water Resource, Gombe, 2003)

The relief of the town ranges between $650 \mathrm{~m}$ in the western part to $370 \mathrm{~m}$ in the eastern parts. Subsequent dissection and stream incision in the area have carved a landscape consisting of flat topped to conical hills, a granitic residuals and pediment landscape. The stratigraphy consists of the alluvium, the Cretaceous Sedimentary Formations of Kerri Kerri Formation, the siltstone, sandstoneand ironstone of the Gombe Formation, the shale and limestone of the Pindiga and Yolde Formation, Bima Formation and the basement rocks (Obaje, 1999).

\section{Material and Methods}

Data used in this study were derived from field measurements, satellite imageries Spot 5 (1999) and Quick Birds (2009) imageries, and laboratory analysis. Three sampled gully profiles were purposively selected for the study. These gullies are second orders and has numerous first orders and cut across the entire town. From each gully profiles, a mean of 55 sample points at $100 \mathrm{~m}$ intervals were delineated, for the measurement of gully morphological variables, while soil samples were taking along the gully wall layers (top, middle and bottom) given a total of 36 sample points or 12 samples per gully profiles at $500 \mathrm{~m}$ interval along the gully profiles in order to analyze the physical and chemical properties of the soil. GPS Garmin eTtrex H, 30m tape, cone penetrometer and soil sampler were used. Data collected were analyzed using a descriptive statistic.

\section{Morphological Characteristics of Gully System of Gombe Town}

The longitudinal profiles of gully A, B and C are presented in Figure 2 (a, b and c). A gully longitudinal profile $\mathrm{A}$ and $\mathrm{C}$ shows the upstream and the midstream, has deeper incisions than the lower stream. This could be due to gradation, slope and catchment sizes of these gully profiles that contribute high volume of runoff into the main gullies and nature of the soil/geology, while gully longitudinal profile of B, showed lower incision. The gully profiles have a flat and steep side walls given it a broad U shaped form (Figure 2a, b, c). The implication of this finding is that gully erosion has deep incision, wide bed and top width that have restricted infrastructural development. 


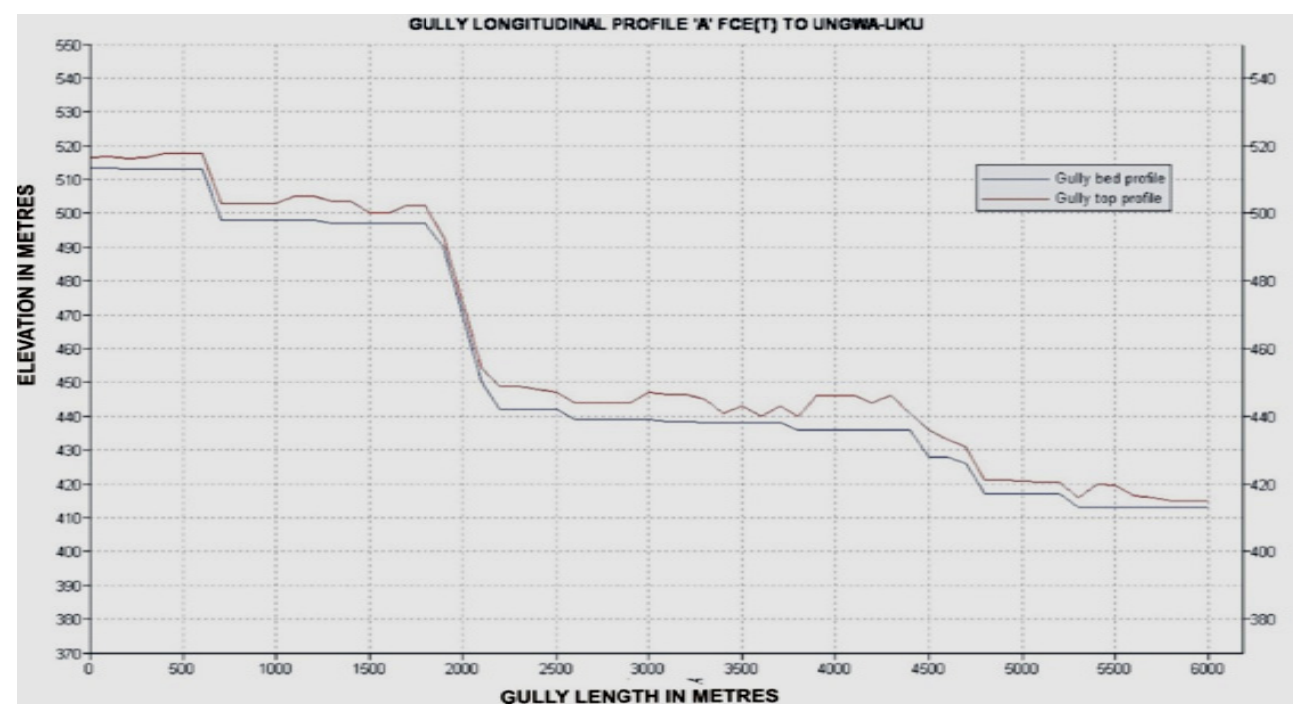

(a)
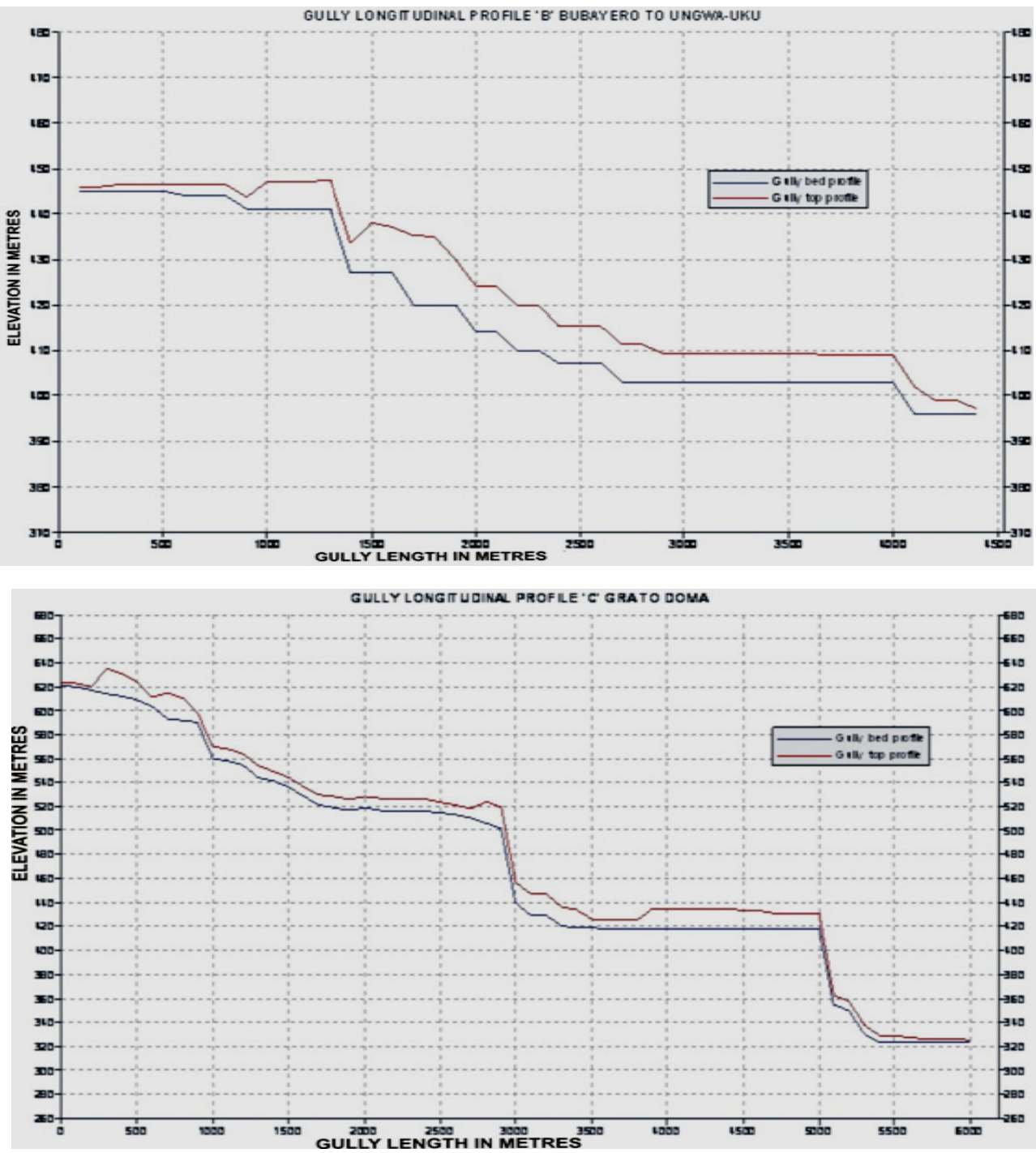

Vertical scale 1: 10; Horizontal scale 1:250

Figure 2. Sample gully longitudinal profiles (Source: Field work, 2010) 
The Spot 5 (1999) and Quick birds (2009) image interpretations and ground truth measurements presented in Figure 3 and Table 1, revealed significant changes in gully morphological variables. Length of gully profiles A, $\mathrm{B}$ and $\mathrm{C}$ range between $4.4 \mathrm{~km}$ in 1999 to $6.0 \mathrm{~km}$ in 2009/2010, representing an increase of $0.2 \mathrm{~km}$ to $0.4 \mathrm{~km}$ or $4.6 \%$ to $7.1 \%$ respectively. Gully depth also witnessed increase from $6.1 \mathrm{~m}$ to $11.8 \mathrm{~m}$ ( gully A, 9.0-10.5m; gully $\mathrm{B}, 6.1-6.7 \mathrm{~m}$ and gully $\mathrm{C}, 9.6-11.8 \mathrm{~m}$ ) respectively, or representing an increase of $9.8 \%$ to $25.6 \%$. The changes in bed widths of the ten years period of satellite images (1999 and 2009) interpretation and 2010 ground truth measurement of these gully profiles, showed an increase from $6.2 \mathrm{~m}$ in 1999 to $52.5 \mathrm{~m}$ in 2009 and 2010 , (gully A, 16.4-20.8m; gully B, 6.2-8.7m and gully C,44.6-52.5m) representing an increase of $4.4 \mathrm{~m}$ to $7.9 \mathrm{~m}$; top width for gully profile A, showed an increase of $2.8 \mathrm{~m}$ or $11 \%(25.5 \mathrm{~m}$ in 1999 to 28.3 in 2009); Gully profile B, also showed an increase of $4 \mathrm{~m}$ or $64.5 \%(7.3 \mathrm{~m}$ to $10.2 \mathrm{~m})$ and gully longitudinal $\mathrm{C}$ witnessed an increase of $11.4 \mathrm{~m}$ or $22.2 \%$ ( $51.4 \mathrm{~m}$ to $62.8 \mathrm{~m}$ ) respectively. Gully area also witnessed an increase of $2.5 \mathrm{~km}^{2}$ in 1999 to $4.6 \mathrm{~km}^{2}$ in 2009 , representing an increase of $2.1 \mathrm{~km}^{2}(84 \%)$ over the last ten years. This implies a mean annual increase of $210 \mathrm{~m}^{2}$. Slope angle for the three gully profiles were $5^{\circ} 4^{\circ}$ and $6^{\circ}$ respectively with mean value of $5^{\circ}$. The relatively no variations in slope angle among the sampled sites is attributed to the low topography of the study area. Iorkua (2006), Rahab (2008) and Ibitoye and Eludoyin (2010) found severe gullies on slope inclined at $3^{\circ}$.

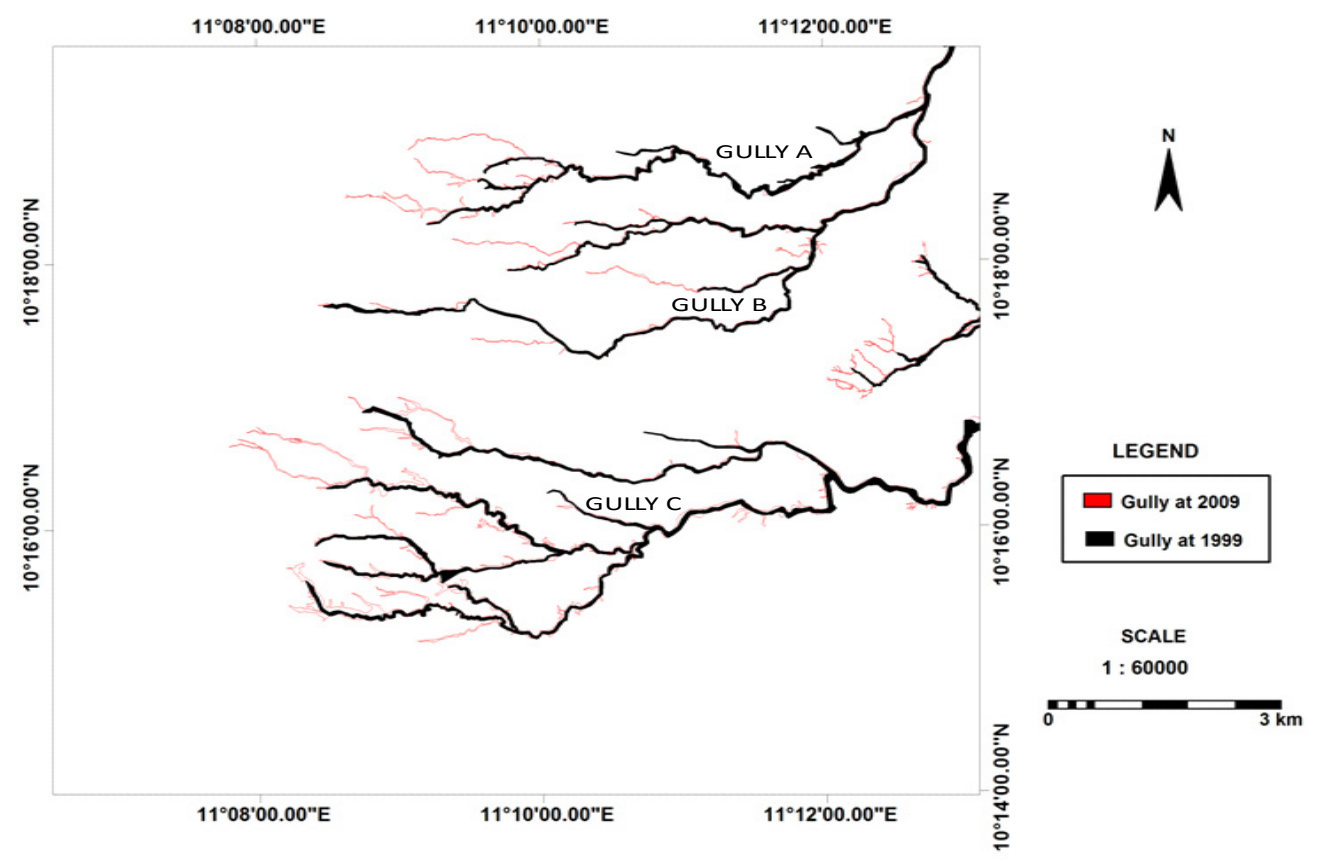

Figure 3. Identified gully density of the study area (Source: Field work / Laboratory Analysis, 2010) 
Table 1. Identified gully quantitative variables derived from spot 5, and quick birds images and field measurement of the study area

\begin{tabular}{|c|c|c|c|c|c|c|c|c|c|c|c|c|c|c|c|c|}
\hline \multirow[b]{2}{*}{$\begin{array}{c}\text { Gully } \\
\text { variable }\end{array}$} & \multicolumn{6}{|c|}{ Gully longitudinal profile A } & \multicolumn{5}{|c|}{ Gully longitudinal profile B } & \multicolumn{4}{|c|}{ Gully longitudinal profile $\mathrm{C}$} & \multirow[b]{2}{*}{$\begin{array}{r}\text { Mear } \\
(\mathrm{m})\end{array}$} \\
\hline & ‘99 & '09 & Changes & $' 10$ & $\begin{array}{c}\text { Changes } \\
\text { between } \\
2009 \& \\
2010\end{array}$ & '99 & ‘09 & Changes & ‘'10 & $\begin{array}{c}\text { Changes } \\
2009 \& \\
2010\end{array}$ & ‘99 & '09 & Changes & ‘10 & $\begin{array}{c}\text { Changes } \\
2009 \& \\
2010\end{array}$ & \\
\hline $\begin{array}{l}\text { Length } \\
(\mathrm{Km})\end{array}$ & 5.6 & 6 & $\begin{array}{l}0.4 \\
(7.1)\end{array}$ & 6 & $\begin{array}{l}0 \\
\text { (0) }\end{array}$ & 4.4 & 4.6 & $\begin{array}{l}0.2 \\
(4.6)\end{array}$ & 4.6 & $\begin{array}{l}0 \\
(0)\end{array}$ & 6 & 6 & $\begin{array}{l}0 \\
(0)\end{array}$ & 6 & $\begin{array}{l}0 \\
\text { (0) }\end{array}$ & 5.5 \\
\hline $\begin{array}{l}\text { Depth } \\
\text { (M) }\end{array}$ & 9.0 & 10.5 & $\begin{array}{l}1.5 \\
(16.6)\end{array}$ & 11 & $\begin{array}{l}0.5 \\
(4.8)\end{array}$ & 6.1 & 6.7 & $\begin{array}{l}0.6 \\
(9.8)\end{array}$ & 7 & $\begin{array}{l}0.3 \\
(4.5)\end{array}$ & 9.0 & 11.3 & $\begin{array}{l}2.3 \\
(25.6)\end{array}$ & 13.5 & $\begin{array}{l}2.2 \\
(19.5)\end{array}$ & 9 \\
\hline $\begin{array}{l}\text { Bed } \\
\text { width } \\
\text { (M) }\end{array}$ & 16.4 & 20.8 & $\begin{array}{l}4.4 \\
(27)\end{array}$ & 22 & $\begin{array}{l}1.2 \\
(5.8)\end{array}$ & 6.2 & 8.7 & $\begin{array}{l}3.7 \\
(23.6)\end{array}$ & 8.8 & $\begin{array}{l}0.1 \\
(1.2)\end{array}$ & 44.6 & 52.5 & $\begin{array}{l}7.9 \\
(17.8)\end{array}$ & 56 & $\begin{array}{l}3.5 \\
(6.7)\end{array}$ & 26.2 \\
\hline $\begin{array}{l}\text { Top } \\
\text { width } \\
\text { (M) }\end{array}$ & 25.5 & 28.3 & $\begin{array}{l}2.8 \\
\text { (11) }\end{array}$ & 30 & $\begin{array}{l}1.7 \\
\text { (6.0) }\end{array}$ & 7.3 & 10.2 & $\begin{array}{l}4.0 \\
(64.5)\end{array}$ & 11.3 & $\begin{array}{l}1.1 \\
(9.2)\end{array}$ & 51.4 & 62.8 & $\begin{array}{l}11.4 \\
(22.2)\end{array}$ & 65 & $\begin{array}{l}2.2 \\
(3.5)\end{array}$ & 32.4 \\
\hline $\begin{array}{l}\text { Slope } \\
\text { angle } \\
\left(0^{\circ}\right)\end{array}$ & 5 & 5 & 0 & 5 & $\begin{array}{l}0 \\
(0)\end{array}$ & 3.8 & 4.0 & 0.2 & 4 & $\begin{array}{l}0 \\
\text { (0) }\end{array}$ & 5.5 & 6 & $\begin{array}{l}0.5 \\
\text { (9) }\end{array}$ & 6 & $\begin{array}{l}0 \\
(0)\end{array}$ & 4.5 \\
\hline $\begin{array}{l}\mathrm{BW} / \mathrm{D} \\
\text { ratio }\end{array}$ & 1.6 & 2.0 & 0.4 & 2.0 & $\begin{array}{l}0 \\
(0)\end{array}$ & 1.0 & 1.3 & 0.3 & 1.3 & $\begin{array}{l}0 \\
(0)\end{array}$ & 7.7 & 8.0 & $\begin{array}{l}0.3 \\
(3.8)\end{array}$ & 8.1 & $\begin{array}{l}0.1 \\
(1.3)\end{array}$ & 3.5 \\
\hline $\begin{array}{l}\mathrm{TW} / \mathrm{BW} \\
\text { ratio }\end{array}$ & 1.6 & 1.3 & 0.3 & 1.4 & 0.1 & 1.2 & 1.2 & 0 & 1.3 & $\begin{array}{l}0.1 \\
(8.3)\end{array}$ & 1.2 & 1.2 & & 1.2 & $\begin{array}{l}0 \\
(0)\end{array}$ & 1.2 \\
\hline $\begin{array}{l}\text { Cross } \\
\text { sec. } \\
\text { Area } \\
\left(\mathrm{M}^{2}\right)\end{array}$ & 188.6 & 257.7 & $\begin{array}{l}69.1 \\
(36.6)\end{array}$ & 286 & $\begin{array}{l}28.3 \\
\text { (11) }\end{array}$ & 40.2 & 63.7 & $\begin{array}{l}23.5 \\
(58.5)\end{array}$ & 70 & $\begin{array}{l}6.3 \\
(10)\end{array}$ & 542 & 696 & $\begin{array}{l}154 \\
(28.4)\end{array}$ & 817 & $\begin{array}{l}121 \\
(17.4)\end{array}$ & 329.1 \\
\hline $\begin{array}{l}\text { Vol. } \\
\text { Soil loss } \\
\text { (t/ha) }\end{array}$ & 1.2 & 1.6 & $\begin{array}{l}0.4 \\
(33.31)\end{array}$ & 1.7 & $\begin{array}{l}0.1 \\
(6.3)\end{array}$ & 0.3 & 0.5 & $\begin{array}{l}0.2 \\
(65.6)\end{array}$ & 0.6 & $\begin{array}{l}0.1 \\
(20)\end{array}$ & 3.3 & 4.2 & $\begin{array}{l}0.9 \\
(27.3)\end{array}$ & 4.9 & $\begin{array}{l}0.7 \\
(16.7)\end{array}$ & 2.0 \\
\hline $\begin{array}{l}* \text { Gully } \\
\text { Area } \\
\left(\mathrm{km}^{2}\right)\end{array}$ & 2.5 & & & & $\begin{array}{l}\text { *- repres } \\
\text { Figures ir }\end{array}$ & $\begin{array}{l}\text { nt the } \mathrm{x} \\
\text { parenth }\end{array}$ & $\begin{array}{l}\text { hole tor } \\
\text { esis rep }\end{array}$ & esent perce & ntage & & & 4.6 & $\begin{array}{l}2.1 \\
(84)\end{array}$ & & & \\
\hline
\end{tabular}

Source: Field work, 2010

\section{Changes in Land Use Type between 1999 and 2009}

The physical growth of Gombe town can be traced to 1919 when the settlement covered just 8 hectares. In 1999 built up area reached $31.21 \mathrm{~km}^{2}$ (Table 2 and Figure 4) and in 2009 the town (Built-up Area) reached $41.67 \mathrm{sq} . \mathrm{km}$, an increased of $10.46 \mathrm{~km}^{2}$. The period between 1999 and 2009 therefore, has witnessed rapid increase in built up area to $10.5 \mathrm{~km}^{2}$ or $33.7 \%$, representing an annual increase of about $1.1 \mathrm{~km}^{2}$. This high increase could be attributed to influx of civil servants and other migrants when Gombe town became the State capital in 1996. Tarred roads and streets also witnessed increase from $0.8 . \mathrm{km}^{2}$ in 1999 to $5.8 \mathrm{~km}^{2}$ in 2009 or $600 \%$ increased over the 10 years images analysis. On the other hand, undeveloped land and open space witnessed significant declined from $4.9 \mathrm{~km}^{2}$ in 1999 to $1.13 . \mathrm{km}^{2}$ in 2009 representing an overall decrease of 75.4 percent. The implication of this growth, and consequent outward expansion, as well as deforestation of the savanna woodland of Gombe town catchment areas, has increase area of impervious surfaces which generated high runoff than infiltration during rainfall events, consequently accelerated gullies. 
Table 2. Changes in landuse type between 1999 and 2009

\begin{tabular}{llllll}
\hline $\mathrm{S} / \mathrm{NO}$ & Landuse Types & 1999 & 2009 & Change $\mathrm{km}^{2}$ & Percentage Changes \\
\hline 1 & Built up areas $\left(\mathrm{km}^{2}\right)$ & 31.21 & 41.7 & +10.5 & 33.7 \\
2 & Tarred Roads $/$ streets $\left(\mathrm{km}^{2}\right)$ & 0.8 & 5.6 & +4.8 & 600 \\
3 & Gullies $\left(\mathrm{km}^{2}\right)$ & 2.54 & 4.6 & +2.06 & 84 \\
4 & Undevelopedland $/$ open space $\left(\mathrm{km}^{2}\right)$ & 4.6 & 1.13 & -3.47 & 75.43 \\
5 & Vegetation cover $\left(\mathrm{km}^{2}\right)$ & 6.2 & 0.6 & -5.6 & 90.32 \\
6 & Total & 45.37 & 53.6 & 26.5 & \\
\hline
\end{tabular}

Sources: Field work, 2010

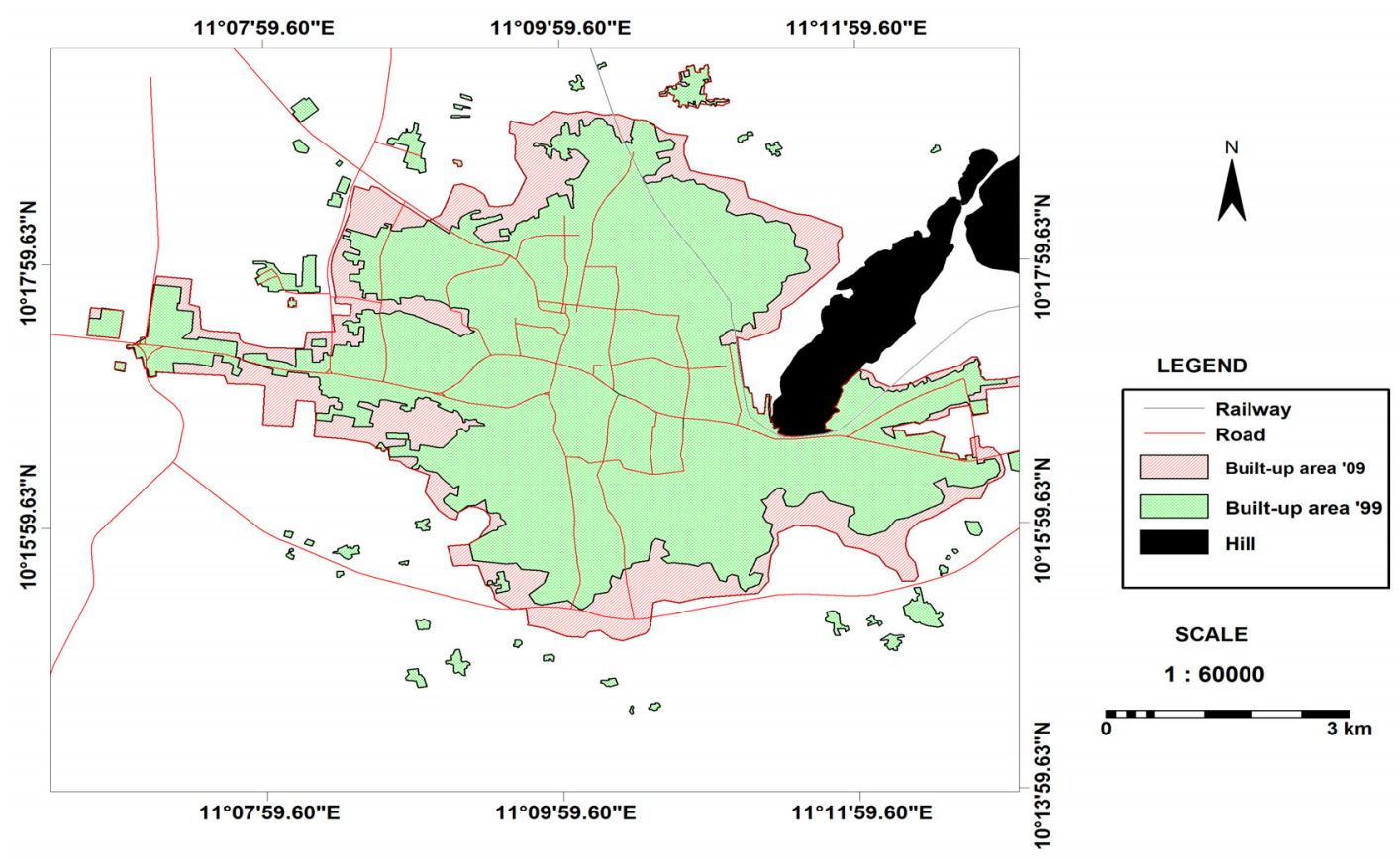

Figure 4. Identified land use changes of gombe town between 1999 and 2009

Source: Field work/ Laboratory Analysis, 2010

\section{Physical Characteristics of the Soil}

The mean particle size distribution of the soil texture along the three sampled gully profiles (Plate 1) is presented in Table 3. Gully profile A, have $78.5 \%$ sand proportion, $5.5 \%$ silt and $16 \%$ clay for top layer; middle layer have $52.5 \%$ sand, $11 \%$ silt and $36.5 \%$ clay; bottom layer have $21 \%$ sand, $7.5 \%$ silt and $71.5 \%$ clay. Gully profile B, showed a mean sand proportion of $73.5 \%, 9.5 \%$ silt and $17.0 \%$ clay for the top layer respectively; middle layer have $59.5 \%$ sand, $8 \%$ silt and $32.5 \%$ clay and bottom layer have $29.5 \%$ sand, $15 \%$ silt and $55.5 \%$ clay respectively. Gully profile $\mathrm{C}$ have mean fraction of $74 \%$ sand, $7.2 \%$ silt and $18.8 \%$ clay for the top layer; middle layer showed $52.7 \%$ sand, $11.5 \%$ silt and $35.8 \%$ clay contents ; and bottom layer showed $23.8 \%$ sand, $182 \%$ silt and $58 \%$ clay respectively. The overall mean proportion for the three sample gully profiles shows $52 \%$ sand, $9.5 \%$ silt and $38.5 \%$ clay for the top, middle and bottom respectively. Olofin, (1990) found that grain size of fine sand to coarse silt ranges up to $50 \%$, while clay alone account for $20-30 \%$ in the northern savanna of Nigeria. The implication of this finding is that with high proportion of sand at the top layer percolation and infiltration is high, while low infiltration at the bottom layer due high proportion of clay content (saturation).This might have increase the falling and slumping of gully walls. The sandstones and shales (Gombe Sandstone and Pindiga Formations) that dominated Gombe town geology have therefore accelerated gully erosion through rock fracture and weathering (Orazurlike, 1987). Thus, physical growth of the town will continue to increase towards the Kerri - Kerri formation in the western part where it is less susceptible to gully erosion. 

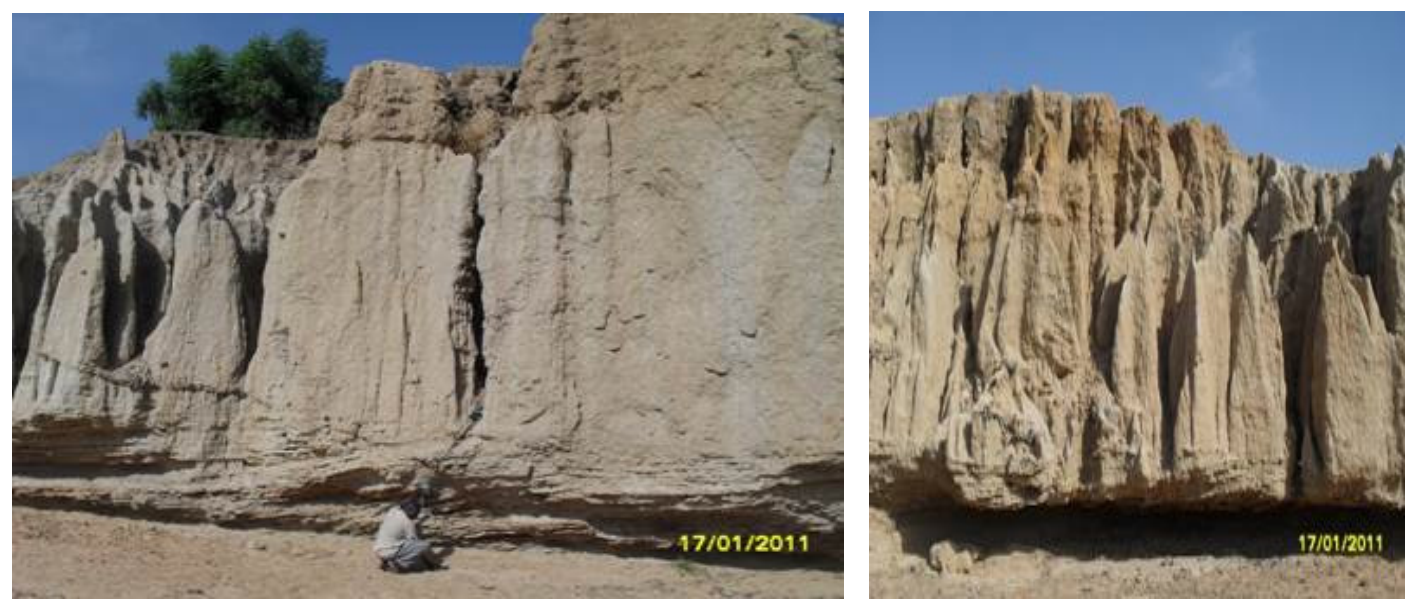

1036 220N 1136 125E (Nayi nawa gullies)

Plate 1. Sampled gully profile layers (Source: Field work, 2010)

Table 3. Results of soil physical properties of the gully profiles

\begin{tabular}{|c|c|c|c|c|c|c|c|c|c|c|c|c|c|}
\hline \multirow{2}{*}{ Soil Property } & \multirow{2}{*}{ Soil Depth } & \multicolumn{3}{|c|}{ Sand (\%) } & \multicolumn{3}{|c|}{ Silt (\%) } & \multicolumn{3}{|c|}{ Clay (\%) } & \multirow[t]{2}{*}{$\mathrm{Tc}$} & \multirow{2}{*}{ F- Test } & \multirow{2}{*}{ Sig. } \\
\hline & & Mean & $\mathrm{Sd}$ & C.V & Mean & $\mathrm{Sd}$ & C.V & Mean & $\mathrm{Sd}$ & C.V & & & \\
\hline \multirow[t]{3}{*}{ Gully Site A } & Top & 78.5 & 9.2 & 1.14 & 5.5 & 1.2 & 4.93 & 16.0 & 7.3 & 4.9 & $\mathrm{Sc}$ & 0.20 & Ns \\
\hline & Middle & 52.5 & 8.9 & 1.63 & 11.0 & 0.9 & 2.25 & 36.5 & 7.0 & 1.67 & $\mathrm{Sc}$ & 0.24 & Ns \\
\hline & Bottom & 21.0 & 9.0 & 3.33 & 7.5 & 0.7 & 12.2 & 71.5 & 4.9 & 1.31 & Sl & 0.18 & Ns \\
\hline \multirow[t]{3}{*}{ Gully Site B } & Top & 73.5 & 7.7 & 1.23 & 9.5 & 2.2 & 13.9 & 17.0 & 6.7 & 4.21 & Sl & 0.21 & $\mathrm{Ns}$ \\
\hline & Middle & 59.5 & 8.5 & 1.47 & 8.0 & 2.1 & 9.90 & 32.5 & 6.6 & 2.55 & Sl & 0.29 & Ns \\
\hline & Bottom & 29.5 & 7.0 & 2.78 & 15.0 & 2.0 & 5.88 & 55.5 & 6.6 & 1.61 & $\mathrm{Scl}$ & 0.25 & Ns \\
\hline \multirow[t]{3}{*}{ Gully Site C } & Top & 74.0 & 4.5 & 1.27 & 7.2 & 2.2 & 18.5 & 18.8 & 6.9 & 3.89 & $\mathrm{Sc}$ & 0.19 & Ns \\
\hline & Middle & 52.7 & 7.0 & 1.67 & 11.5 & 3.8 & 6.54 & 35.8 & 4.1 & 2.51 & $\mathrm{Scl}$ & 0.27 & Ns \\
\hline & Bottom & 23.8 & 4.9 & 3.48 & 18.2 & 5.0 & 6.14 & 58.0 & 8.4 & 1.40 & $\mathrm{Scl}$ & 0.16 & Ns \\
\hline Mean & & 52 & 7.4 & 2.0 & 9.5 & 2.2 & 9.2 & 38.5 & 6.5 & 2.7 & & & \\
\hline
\end{tabular}

TC - Textural Class, SL - Sandy loam, SCL - Sandy clay loam, SC - Sandy clay, NS - Not significant

Source: Field work/ Laboratory Analysis, 2010.

\section{Soil Chemical Properties of the Sample Gully Profiles}

The average soil $\mathrm{pH}$ (Table 4) values of top layer for the three gully profiles were 6.2, 5.7 and 5.6; middle layer mean values were 4.5, 5.3 and 4.2 and the bottom layer has mean values of 3.6, 3.3 and 3.5 respectively, with overall mean of 4.6 and there was no significant difference $(\mathrm{P}>0.05)$ among the sampled gully profiles. This implied that the soils are moderately acidic. Arabi et al. (2010) found similar $\mathrm{pH}$ values in Gombe. Table 4, further shows decreases in soil $\mathrm{pH}$ mean values from top layer down the soil profiles. The implication of this finding is that the soil of the study area may not be affected by micro organisms that work on organic matter which might enhance the binding of soils to resists erosivity of rainfall and runoff impact. This finding also has implication on crop cultivation and growth of paniculatu / Pitadeniastrum africanum to check gully erosion in the study area. The overall patterns of variation of exchangeable cation $(\mathrm{Ca}, \mathrm{Mg}, \mathrm{Na}$ and $\mathrm{K}$ ) in Table 4, from top to the bottom of the gully profiles were similar. The mean values of calcium $(\mathrm{Ca})$ for gully profile $\mathrm{A}$, ranges from 1.8 to $2.2 \mathrm{meg} / 100$; gully profile $\mathrm{B}, 1.5$ to $2.7 \mathrm{meg} / 100$ and gully profile $\mathrm{C}$, ranges from 1.5 to $2.5 \mathrm{meg} / 100$ respectively. Potassium (K) ranges between 0.1 to $0.3 \mathrm{meg} / 100$ for gully profile A, B and C. Magnesium (Mg) values ranges between 0.2 to $0.3 \mathrm{meg} / 100$ for gully profiles $\mathrm{A}, \mathrm{B}$ and $\mathrm{C}$ respectively. There is a general increase in mean values for both soil layers. On the whole the valley bottom soils were more enriched with the basic elements, while the top or middle layer recorded the lowest mean values. This may be explained in terms of the relative steepness of the gully walls and hence downward of the basic elements and subsequent accumulation at the valley floor. Exchangeable sodium $(\mathrm{Na})$ on the other hand showed an irregular increase and decreased in 
mean values from top to the bottom layer of the gully walls. The three layers showed of all the gully profiles ranges from 0.1 to $0.9 \mathrm{meg} / 100$. These variations might be due to mineral constituent of urban waste disposal and the sewage that are washed away into these gully sites. Jeje and Agu (1990) found that gully erosion affect exchangeable cations and characteristics, by low infiltration rate and very low holding capacity. The implication of this findings to biological control of gully erosion, is that increased in $\mathrm{Na}$ can have negative effects on the soil fertility and hence retard the growth of plants such as paniculatu/Pitadeniastrum africanum which are regarded as the most effective method of controlling gully erosion because of its affordability, accessibility and adaptability. The results of soils organic matter content (OMC) in Table 4 showed the mean value of gully site A, $\mathrm{B}$ and $\mathrm{C}$ (top, middle and bottom gully wall layers) ranges from 0.6 to 1.3 , which is considered low. The overall pattern of variation showed a downward increase in the organic contents. Mills and Fey (2003) also found a linear decrease in erodibility with increasing organic content over a range of 0 to $10 \%$. However, there was significant differences at the top and bottom layers of the gully walls $(\mathrm{P}>0.05)$. The possible causes of these differences might be attributed to leaching of the organic matter down the valley floors of the gully site. Orazulike (1992) also found that the soils are deficient in plant nutrients. The organic content of all the soil samples falls below $2 \%$, which is considered as the threshold below which soils are erodible. Sealing and high surface runoff is also more pronounced in soils with very low organic content. A poor soil structure and low plant nutrient content will cause the soil to be more prone to gully erosion. This might be the reason behind the present distribution of gully erosion in this case study. This have negative implication on tree planted to check gully erosion and on food security, unless more chemical fertilizer is provided. The results of soil phosphorus test (Table 4) showed downward decreases in mean values from top to the bottom layers of the three sampled gully sites. Gully site A, B and C top layers have mean values of 1.4 to $3.2 \mathrm{meg} / 100$; middle layer have 1.5 to 2.6 $\mathrm{meg} / 100$ and bottom layer mean values ranges from 1.2 to $3.0 \mathrm{meg} / 100$ respectively. Analysis of variance showed significant differences in the three layers of the gully profiles. This value is low, and translates low phosphorus in the soil. Ayuba (1992) observed that, the Nigerian savanna is characterized by low phosphorus. The implication of this finding is that phosphorus is important in plant- soil- water interaction and in the general biogeochemical cycling in natural system. There is the need to set-up phosphorus level in the prone gully sites to meet the demand for phosphorus, more especially when panting paniculatu / Pitadeniastrum africanum in checking gully erosion in the study area.

Table 4. Soil chemical properties of sample gully profiles

\begin{tabular}{|c|c|c|c|c|c|c|c|c|c|c|c|c|}
\hline \multirow{2}{*}{ Soil Property } & \multirow{2}{*}{ Soil Depth } & \multicolumn{3}{|c|}{ Gully Site A } & \multicolumn{3}{|c|}{ Gully Site B } & \multicolumn{3}{|c|}{ Gully Site C } & \multirow{2}{*}{ F- test } & \multirow{2}{*}{ Sig } \\
\hline & & Mean & SD & C.V & Mean & SD & C.V & Mean & SD & C.V & & \\
\hline \multirow[t]{3}{*}{ OM $\%$} & Top & 0.8 & 0.01 & 123.4 & 0.8 & 0.32 & 89.3 & 1.3 & 0.00 & 76.9 & 0.001 & $\mathrm{~S}$ \\
\hline & Middle & 0.8 & 0.01 & 123.4 & 0.7 & 0.01 & 140.8 & 0.6 & 0.00 & 166 & 0.313 & NS \\
\hline & Bottom & 1.3 & 0.20 & 66.6 & 0.8 & 0.01 & 123.4 & 0.6 & 0.00 & 166 & 0.019 & $\mathrm{~S}$ \\
\hline \multirow{3}{*}{$\begin{array}{l}\text { Calcium } \\
\mathrm{meg} / 100 \mathrm{~g}\end{array}$} & Top & 1.8 & 2.34 & 39.3 & 1.6 & 0.20 & 11.9 & 1.5 & 0.21 & 10.3 & 0.153 & NS \\
\hline & Middle & 2.0 & 2.32 & 17.2 & 1.5 & 0.44 & 10.1 & 1.5 & 0.40 & 9.17 & 0.02 & S \\
\hline & Bottom & 2.2 & 2.43 & 12.3 & 2.7 & 0.52 & 9.8 & 2.5 & 0.35 & 12.7 & 0.01 & $\mathrm{~S}$ \\
\hline \multirow[t]{3}{*}{ NA meg $/ 100 \mathrm{~g}$} & Top & 0.1 & 0.01 & 123.4 & 0.8 & 0.00 & 125.0 & 0.4 & 0.01 & 99.0 & 0.008 & NS \\
\hline & Middle & 0.2 & 0.01 & 99.0 & 0.9 & 0.00 & 111.1 & 0.9 & 0.00 & 111 & 0.301 & NS \\
\hline & Bottom & 0.2 & 0.01 & 123.4 & 0.8 & 0.01 & 123.4 & 0.5 & 0.00 & 200 & 0.571 & NS \\
\hline \multirow[t]{3}{*}{$\mathrm{K} \mathrm{meg} / 100 \mathrm{~g}$} & Top & 0.12 & 0.35 & 19.8 & 0.2 & 0.01 & 45.2 & 0.4 & 0.01 & 71.3 & 0.002 & $\mathrm{~S}$ \\
\hline & Middle & 0.2 & 0.20 & 35.7 & 0.1 & 0.01 & 99.0 & 0.5 & 0.01 & 66.6 & 0.016 & $\mathrm{~S}$ \\
\hline & Bottom & 0.2 & 0.25 & 32.8 & 0.30 & 0.01 & 99.0 & 0.21 & 0.01 & 47.4 & 0.005 & $\mathrm{~S}$ \\
\hline \multirow[t]{3}{*}{$\mathrm{Mg}$ meg/100g } & Top & 0.2 & 0.24 & 36.5 & 0.3 & 0.25 & 32.7 & 0.2 & 0.22 & 35.5 & 0.032 & NS \\
\hline & Middle & 0.3 & 0.31 & 30.2 & 0.3 & 0.24 & 24.8 & 0.3 & 0.31 & 32.5 & 0.006 & $\mathrm{~S}$ \\
\hline & Bottom & 0.3 & 0.32 & 29.2 & 0.23 & 0.01 & 33.2 & 0.23 & 0.34 & 24.2 & 0.023 & NS \\
\hline \multirow[t]{3}{*}{ P meg/100g } & Top & 2.3 & 1.70 & 4.80 & 3.2 & 5.99 & 2.60 & 1.4 & 1.2 & 4.6 & 0.001 & $\mathrm{~S}$ \\
\hline & Middle & 2.6 & 1.67 & 7.30 & 2.0 & 5.98 & 3.87 & 1.5 & 1.2 & 3.9 & 0.002 & $\mathrm{~S}$ \\
\hline & Bottom & 3.0 & 1.72 & 7.60 & 3.0 & 5.95 & 4.35 & 1.2 & 1.2 & 6.09 & 0.005 & $\mathrm{~S}$ \\
\hline
\end{tabular}

$\mathrm{OM}$ - Organic matter, $\mathrm{Na}$ - Sodium $\mathrm{K}$ - Potassium $\mathrm{Mg}$ - Magnesium, $\mathrm{P}$ - Phosphorus

Source: Laboratory Analysis, 2012. 


\section{Geotechnical Properties of the Sample Gully Profiles}

The mean soil bulk density for the sampled gully profiles presented in Table 5 ranges between 1.9 to $2.2 \mathrm{~g} / \mathrm{cm}^{3}$ for gully profile A, B and C respectively. These values are high indicating that the soil is compacted. Moisture contents mean values for the three sampled gully profiles ranges between 9.8 to $16.7 \mathrm{~g} / \mathrm{cm}^{3}$ for gully profile A B and $\mathrm{C}$ respectively. This implied low values, this could have contributed to the long dry season despite the impact of urban waste water that flow into these gully sites. This will have implication on the survival of paniculatu / Pitadeniastrum africanum planted to check gully erosion. The mean values of cohesion for gully profiles $\mathrm{A}, \mathrm{B}$ and $\mathrm{C}$ has the same values of $0.2 \mathrm{~kg} / \mathrm{cm}^{3}$, for the top, middle and bottom respectively. The mean angle of internal friction for gully profiles A.B and $\mathrm{C}$ for the top layer were $26.5^{\circ}, 26.6^{\circ}$ and $25.5^{\circ}$ respectively; middle layer has mean values of $24^{\circ}$ and $26^{\circ}$; and bottom layer has mean values of $26^{\circ}, 28^{\circ}$ and $26^{\circ}$ respectively. The importance of this test is that the force due to runoff and the seepage flux are only resisted by the angle of internal friction when the value is $>40^{\circ}$ (Obiefuna et al., 1999). Since the mean angle of internal friction of this study area is below $40^{\circ}$ (Table 5), gully erosion in the study area could partly explained due to low shear strength of the soils. The results of this finding will help civil engineers whose activities border gully erosion control, construction road and drainage and houses. The result of porosity for gully profile A, B and C ranges between $43 \%$ and $45.5 \%$ at the top layer as; the middle layer has 43 to $51 \%$ and the bottom layer ranges between 38 to $47.5 \%$ respectively. Gully profile A and C are the most porous, probably due to the nature of the soil and degree of sealing surfaces. This finding is within the range of $35-50 \%$ and therefore, the soil is porous. A similar result was obtained by Rahab (2008) in Zaria. The implication of this finding is that gully incision and side wall slumping will continue to increase, thereby increasing headward progression of gullies and destruction of more house.

Table 5. Atterberg limits and geological properties of soil samples gully profiles

\begin{tabular}{|c|c|c|c|c|c|c|c|c|c|c|c|c|}
\hline \multirow{2}{*}{ Soil Property } & \multirow{2}{*}{ Soil Depth } & \multicolumn{3}{|c|}{ Gully Site A } & \multicolumn{3}{|c|}{ Gully Site B } & \multicolumn{3}{|c|}{ Gully Site C } & \multirow{2}{*}{ F- test } & \multirow{2}{*}{ Sig. } \\
\hline & & Mean & SD & C.V\% & Mean & SD & C.V\% & Mean & SD & C.V & & \\
\hline \multirow[t]{3}{*}{ LL \% } & Top & 27.4 & 0.8 & 3.5 & 26.5 & 1.1 & 3.6 & 27.0 & 1.0 & 0.3 & 0.03 & NS \\
\hline & Middle & 28.2 & 0.7 & 3.4 & 27.0 & 1.0 & 3.7 & 27.1 & 1.0 & 0.3 & 0.12 & NS \\
\hline & Bottom & 26.9 & 0.9 & 3.6 & 26.0 & 1.1 & 3.5 & 27.0 & 0.5 & 0.2 & 0.12 & NS \\
\hline \multirow[t]{3}{*}{ PL\% } & Top & 22.4 & 1.4 & 3.8 & 21.5 & 0.6 & 3.5 & 22.9 & 0.8 & 0.2 & 0.35 & NS \\
\hline & Middle & 22.7 & 1.3 & 4.0 & 22.5 & 0.5 & 4.3 & 22.9 & 0.7 & 0.2 & 0.32 & NS \\
\hline & Bottom & 24.4 & 1.5 & 3.8 & 22.0 & 0.6 & 4.3 & 22.6 & 0.7 & 0.2 & 0.03 & NS \\
\hline \multirow{3}{*}{$\begin{array}{l}\text { Cohesion } \\
\mathrm{Kg} / \mathrm{M}^{2} \text { ) }\end{array}$} & Top & 0.2 & 0.0 & 500 & 0.2 & 0.2 & 250 & 0.2 & 0.0 & 0.0 & 0.02 & NS \\
\hline & Middle & 0.2 & 0.0 & 500 & 0.2 & 0.2 & 250 & 0.2 & 0.0 & 0.0 & 0.30 & NS \\
\hline & Bottom & 0.2 & 0.0 & 500 & 0.3 & 0.2 & 200 & 0.2 & 0.0 & 0.02 & 0.33 & NS \\
\hline \multirow{3}{*}{$\begin{array}{l}\text { AIF } \\
\left(Q^{0}\right)\end{array}$} & Top & 26.5 & 0.6 & 3.6 & 26.6 & 0.17 & 3.5 & 25.5 & 0.06 & 0.02 & 0.23 & NS \\
\hline & Middle & 24 & 0.6 & 4.1 & 26 & 0.17 & 3.6 & 26 & 0.06 & 0.02 & 0.14 & NS \\
\hline & Bottom & 26 & 0.6 & 3.8 & 28 & 0.15 & 3.5 & 26 & 0.05 & 0.02 & 0.21 & NS \\
\hline \multirow{3}{*}{$\begin{array}{l}\text { Porosity } \\
(\%)\end{array}$} & Top & 45.5 & 0.0 & 2.2 & 44 & 0.00 & 2.2 & 43.0 & 1.28 & 0.5 & 0.25 & NS \\
\hline & Middle & 46.5 & 0.0 & 2.2 & 43 & 0.00 & 2.3 & 51.0 & 1.26 & 0.7 & 0.12 & NS \\
\hline & Bottom & 38.5 & 0.0 & 2.6 & 42 & 0.00 & 2.3 & 47.5 & 1.27 & 0.6 & 0.35 & NS \\
\hline \multirow{3}{*}{$\begin{array}{l}\text { Bulk Density } \\
\left(\mathrm{g} / \mathrm{cm}^{3}\right)\end{array}$} & Top & 2.0 & 0.2 & 49.5 & 1.8 & 0.2 & 50.0 & 1.6 & 0.3 & 52.6 & 0.02 & NS \\
\hline & Middle & 2.2 & 0.3 & 40.0 & 2.2 & 0.3 & 40.0 & 2.2 & 0.2 & 41.7 & 0.02 & NS \\
\hline & Bottom & 1.9 & 0.2 & 47.6 & 2.9 & 0.2 & 32.3 & 2.3 & 0.4 & 2.89 & 0.13 & NS \\
\hline \multirow{3}{*}{$\begin{array}{l}\text { Moisture Content } \\
\mathrm{g} / \mathrm{cm}^{3}\end{array}$} & Top & 10.5 & 0.6 & 9.01 & 10.6 & 0.6 & 8.92 & 9.8 & 0.6 & 9.6 & 0.15 & NS \\
\hline & Middle & 11.9 & 0.7 & 8.62 & 13.7 & 0.5 & 8.92 & 10.9 & 0.7 & 8.6 & 0.24 & NS \\
\hline & Bottom & 12.8 & 0.5 & 8.85 & 16.7 & 0.6 & 8.85 & 14.5 & 0.8 & 8.8 & 0.14 & NS \\
\hline
\end{tabular}

LL - Liquid limit, PL - Plasticity limit, AIF - Angle of internal friction.

Source: Field work/ Laboratory Analysis, 2012 
The results of Atterberg limits (liquid limit, plasticity limit and plasticity index), is presented in Table .5. The liquid and plastic limits were measured used to obtain the plasticity index, which is a measure of the plasticity of the soil. The liquid limits (LL) for gully profile A; top , middle and bottom layers are $27.4 \%, 28.2 \%$ and $29.6 \%$ respectively; Gully profile B has mean values of $26.5 \%, 27.0 \%$ and $26 \%$ and gully profile $\mathrm{C}$ have mean values of 27.0 for the three layers respectively. The analysis further revealed no significant difference in LL ( $P>0.05)$ among the sampled gullies. The plasticity limits (PL) for gully profile A, for the top, middle and bottom layers of the are $22.4 \%, 22.7 \%$ and $24.4 \%$ respectively; gully profile B has mean values of $21.5 \%, 22.5 \%$ and $22 \%$ and gully profile C has $22.9 \%, 22.9 \%$ and $22.6 \%$ respectively for the top, middle and bottom layers of the sampled soils. Low LL and PL in these soils made the soil to be loose, non-coherent and to slide upon getting in contact with water or even to disintegrate under dry conditions. Obiefuna (1999 and 2010) in Yola town and Igwe and Ejiofor (2005) in Central eastern, Nigeria found similar values.

\section{Rainfall Characteristics}

Table 6. Main characteristics of rainfall events in the study area: total height $(\mathrm{Ht})$, rainy days $(\mathrm{Dr})$, maximum $\leq$ 30 min max intensity, maximum $\geq 1$-h height $\left(\mathrm{H}_{\max 1}-\mathrm{h}\right)$

\begin{tabular}{ccccc}
\hline Hydrological Year & $\mathrm{Ht}$ & $\mathrm{Dr}$ & $\leq 30 \mathrm{~min} \max$ & $\geq \mathrm{I}-\mathrm{h} \max$ \\
\hline 1996 & 664.5 & 51 & $\mathrm{Nd}$ & 75.4 \\
1997 & 986.6 & 60 & $\mathrm{Nd}$ & 54.6 \\
1998 & 1041.6 & 63 & $\mathrm{Nd}$ & 90.0 \\
1999 & 965.9 & 59 & $\mathrm{Nd}$ & 89.2 \\
2000 & 947.5 & 54 & $\mathrm{Nd}$ & 39.6 \\
2001 & 728.3 & 34 & $\mathrm{Nd}$ & 75.4 \\
2002 & 851.2 & 50 & $\mathrm{Nd}$ & 54.6 \\
2003 & 1051.6 & 53 & $\mathrm{Nd}$ & 123.7 \\
2004 & 796.5 & 50 & $\mathrm{Nd}$ & 42.3 \\
2005 & 810.0 & 53 & $\mathrm{Nd}$ & 43.7 \\
2006 & 940.0 & 60 & $\mathrm{Nd}$ & 94.5 \\
2007 & 881.0 & 51 & $\mathrm{Nd}$ & 62.4 \\
2008 & 946.0 & 61 & 42.3 & 108.3 \\
2009 & 846.0 & 59 & 32.2 & 64.6 \\
2010 & 576.0 & 55 & 28.2 & 86.8 \\
Mean & 800 & 54.1 & 34.2 & 73.7 \\
SD & 135.35 & 6.45 & 2.83 & 22.93 \\
\hline
\end{tabular}

$\mathrm{Nd}$ - no data, SD - standard deviation

Source: Meteorological Station Gombe (2010)

Gully erosion, is a threshold phenomenon in terms of flow hydraulics and rainfall. Table 6 shows the rainfall variability of the 15 hydrologic years, particularly with regards to annual rainfall. It revealed that of the 15 years period under study, only 4 years (1996, 2001, 2004 and 2010) has total annual rainfall less than the mean annual $(800 \mathrm{~mm})$, while the 11 years received more than the mean annual total, representing $73.3 \%$. This implies that only $26.7 \%$ of the 15 hydrologic years has relatively low rainfall compared with the mean total height of $800 \mathrm{~mm}$. However, this amount is high in an urban environment with increasing sealing surfaces. This finding agreed with Ologe (1987), who found out those stations with mean annual rainfall of $762 \mathrm{~mm}$ to $1524 \mathrm{~mm}$ lies within the maximum fluvial erosion. The mean annual rainfall days (Dr) showed 54 days, with a maximum of 63 days (1998), minimum of 34 days (2001) and standard deviation of 6.45. This showed low variation in rainfall days, however, this does not implied that the higher the number of rainy days the higher the amount of rainfall expected as shown in table Rainfall duration of $\leq 30 \mathrm{~min}$ for the year 2008- 2010 showed a mean of $34.2 \mathrm{~mm}$ with standard deviation of 2.83. This finding agreed with similar work carried by Nyanganji (1997) and Capra et al. (2009), who found out that most of erosive rainfall events occurred during the first 15 and 30 minutes of rainfall. The maximum rainfall intensity of $\geq \mathrm{I}-\mathrm{hr}$ ranges between $39.6 \mathrm{~mm}$ to $123.7 \mathrm{~mm}$ and standard deviation of 22.93 respectively. These intense storms with mean of $25 \mathrm{~mm}$ per hour on exposed surfaces such as the study area 
accelerate gullies. Capra et al., (2009) reported that a rainfall event is erosive if the height of rainfall is equal to or more than $13 \mathrm{~mm}$ per hour or the intensity in $15 \mathrm{~min}$ is equal to or more than $6 \mathrm{~mm}$. The implication of this finding is that every year gully erosion increases due to rainfall intensity that produces rapid saturation of the soil, causing down cutting. These intense storms with mean of $25 \mathrm{~mm}$ per hour on exposed surfaces such as the study area accelerate gullies. This finding agreed with Capra et al. (2009), who reported that a rainfall event is erosive if the height of rainfall is equal to or more than $13 \mathrm{~mm}$ per hour or the intensity in $15 \mathrm{~min}$ is equal to or more than $6 \mathrm{~mm}$. The implication of this finding is that every year gully erosion increases due to exceeding rainfall threshold.

\section{Topography (Slope Length and Gradient)}

A GPS reading taken at Yola / Bauchi junction shows $626.3 \mathrm{~m}$ above sea level and at the round about (old market) $454.8 \mathrm{~m}$ a.s.1, representing a height difference of $171.5 \mathrm{~m}$ through a distance of about $3 \mathrm{~km}$. The same GPS reading was taken around PHCN power station along Dukku road which showed $603.5 \mathrm{~m}$ representing a difference of $148.7 \mathrm{~m}$ with that of old market (centre of the town) through a distance of about $3 \mathrm{~km}$ and mean slope gradient of $5^{\circ}$. This is considered high gradient for unprotected surface. The slope length indicates the gravity of low infiltration and high runoff conditions. Ebisemiju (1989) found out that slope gradient alone explains about $63 \%$ of the spatial variations in the intensity of gully erosion in Guyana. The implication of this finding is that Gombe town is dominated by active gully erosion and there is the need for holistic approach to watershed management. Ordinarily under vegetal cover, this slope gradient should not have enhanced erosion processes (Figure 5), but due to exposure to direct raindrop impact, human activities and coupled with the poor soil aggregate has accelerated gully erosion.

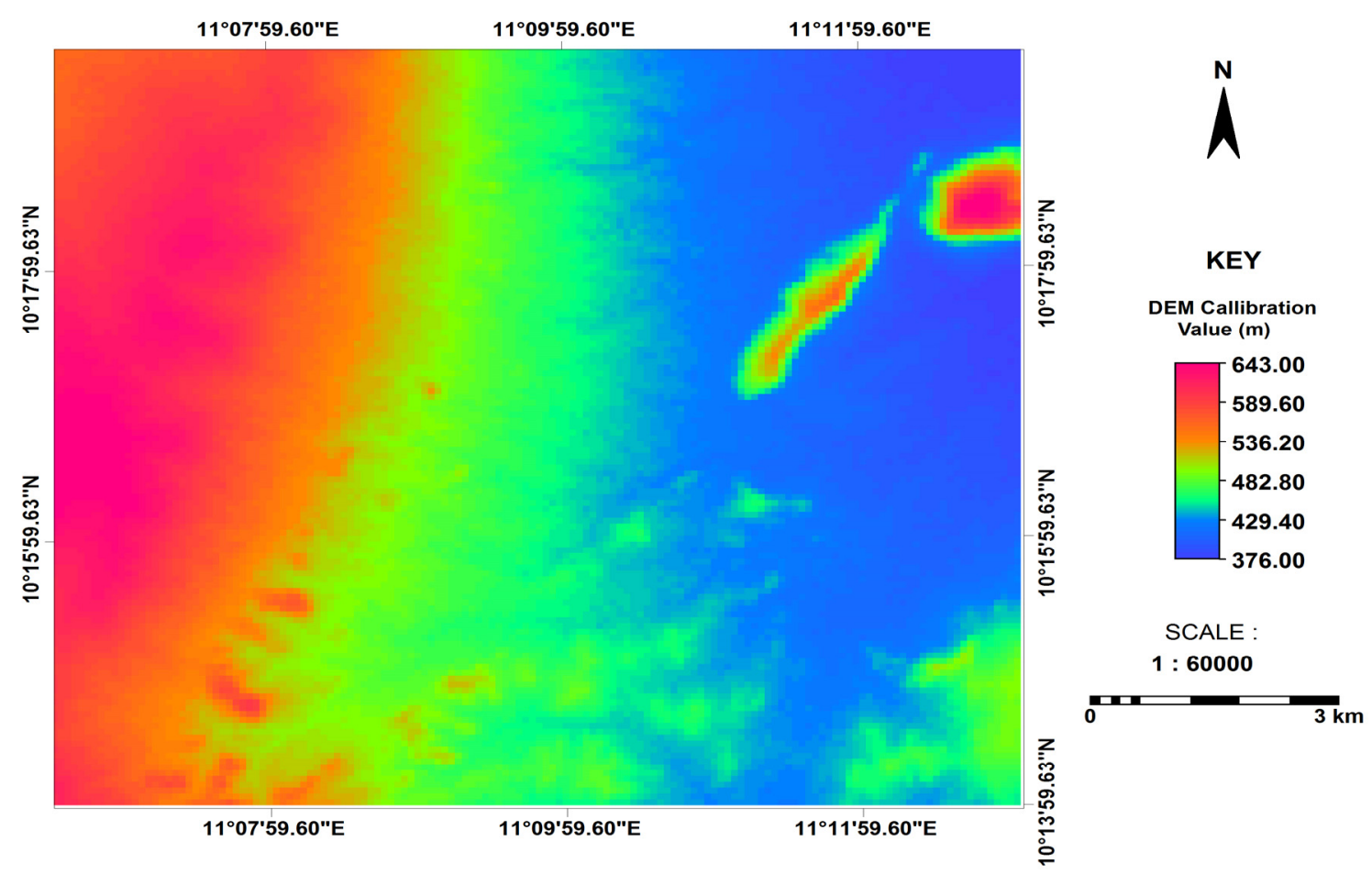

Figure 5. Slope map of the study Area (Source: Field work, 2010)

\section{Conclusions}

Gombe town is facing serious problem of gully erosion causing untold hardships and misery on the lives of the people. Complex interdependent mechanisms between rainfall characteristics, soil erodibility, land use, topography has reduced infiltration, which caused a higher surface runoff. This has increased deep cutting, take up valuable land, raised the cost of building and sinking of well water This chain of cause and effect hits most of the low income groups of the community, where the population density is highest and where the worst damages of gully erosion are found. 


\section{References}

Ayuba, H. K. (1992). Effects of Continues Cultivation on the Soil and Vegetation in Konduga L.G.A of Borno State. Unpublished M.Sc Dissertation, University of Ibadan

Balzerek, H., Werner, F., Jürgen, H., Klaus-martin, M., \& Markus, R. (2003). Man Made Flood Disaster in the Savanna Town of Gombe/NE Nigeria. Erdkunde, 57(2), 94-109. http://dx.doi.org/10.3112/erdkunde.2003.02.02

Capra, A., \& Porto, S. B. (2009). Relationship between Rainfall Characteristics and Ephemeral Gully Erosion in a Cultivated Catchment in Sicily. Soil \& Tillage Research, 105(1), 77-87. http://dx.doi.org/10.1016/j.still.2009.05.009

Ebisemiju, F. S. (1989). A Morphometric approach to gully analysis. Geomorphologies, 33(3), 307-322.

Ibitoye, M., \& Eludoyin, A. (2010). Urban Growth and Development of Soil erosion in part of Humid of Southwest Nigeria. FIG Congress 2010 Facing the Challenges - Building the Capacity Sydney, Australia, 11-16 April 2010.

Iorkua, S. A. (2006). A study of Inter- relationships among Gully elements in North Bank Makurdi. In Aonogo, L., \& Daniel, S. O. (eds) Journal of Geography and Development, 1(1), 32-49.

Jeje, L. K., \& Agu, A. N. (1990). Run-off from Bounded Plots in Alakowe in South Western Nigeria. Applied Geography, 10, 63-74. http://dx.doi.org/10.1016/0143-6228(90)90005-A

Mbaya, L. A. (2012). An Assessment of Gully Erosion in Gombe Town, Nigeria. Unpublished Ph.D Thesis, University of Maiduguri.

Mills, A. J., \& Fey, M. V. (2003). Declining Soil Quality in South Africa: effects of land use on soil organic matter and surface crusting. South Africa. Journal of Science, 99, 429-436.

Nyanganji, J. K. (1997). Some Basic Observations on Rainfall and Runoff related Factors on an Artificial Catchment in Maiduguri, NE Nigeria. In: Daura (ed) Issues in Environmental Monitoring in Nigeria, 152-165.

Obaje, N. G., Abaa, S. I., Najime, T., \& Suh, C. E. (1999). Economic geology of Nigerian Coals Resources: A Brief Review. Afr. Geosci. Rev., 6, 71-82.

Obiefuna, G. I., Nur, A., Baba, U., \& Bassey, N. E. (1999). Geological and Geotechnica Assessment of selected Gully Sites in Yola area, Northeast, Nigeria. Journal of Environmental Hydrology, 7, 33-45.

Obiefuna, G. I., Oreagbune, I. M., \& David, C. (2010). Geotechnical Evaluation of Soils in Numan and its Environs, Northeast Nigeria. Continental J. Earth Sciences, 5(1), 20-31.

Olofin, E. A. (1992). The Dynamics of Gully Head Recession in a Savanna Environment. Erosion, Transport and Deposition Processes (Proceedings of Jeruselem Workshop), IAHS, NO.189

Ologe, K. O. (1987). Soil erosion characteristics, processes and extent in the Nigerian savanna. In V. O. Sagua, E. E. Enabor, G. E. K. Ofomata, K. O. Ologe, \& L. Oyebande (eds) Ecological Disasters in Nigeria: Soil erosion, 26-49.

Orazulike, D. M. (1992). A Study of Gully Phenomenon in Gombe Town, Bauchi State: Bedrock Geology and Environmental Implications, 200-201. Kluwer Academic Publisher, Netherlands.

Rahab, N. (2008). Effects of Soil Physical Properties on Gully Morphology in Zaria, Northern Nigeria. A paper presented at the $48^{\text {th }}$ Annual Conference of Association of Nigerian Geographers, held at the Department of Geography, University of Calabar, October 2008. 